\title{
HYPERPHOSPHORYLATED TAU PROTEIN IN THE CEREBROSPINAL FLUID OF PATIENTS WITH ALZHEIMER'S DISEASE AND OTHER DEMENTIAS
}

\author{
Preliminary findings
}

\author{
Ana Paula Barbosa Jeronimo Hartmann', Sérgio Monteiro de Almeida², \\ José Antonio Livramento ${ }^{3}$, Ricardo Nitrini ${ }^{3}$, Daniel Takahashi ${ }^{4}$, Paulo Caramelli ${ }^{5}$
}

\begin{abstract}
Alzheimer's disease (AD) is pathologically characterized by the accumulation of amyloid plaques and tau-associated neurofibrillary tangles in the cerebral tissue. The search for antemortem biomarkers is intense including analysis of cerebrospinal fluid (CSF) $\beta$-amyloid and tau proteins concentrations seeking for an accurate and early diagnosis. Levels of hyperphosphorylated tau at threonine 181 were measured in the CSF of 34 patients with AD (19 with senile AD - SAD and eight with presenile AD - PSAD) and seven with other dementias (OD). The levels of CSF phosphotau were significantly higher in the $A D$ patients compared to OD (AUC 0.812), with no association with severity of dementia, age of onset, duration of the disease or scores in the Mini-Mental State Examination. There were no differences of phosphotau levels between SAD and PSAD patients. These findings corroborate some previous studies and indicate that CSF phosphotau may help to differentiate AD from other dementias.
\end{abstract}

KEY WORDS: Alzheimer's disease, differential diagnosis, cerebrospinal fluid, tau protein.

\begin{abstract}
Proteína tau hiperfosforilada no líquido cefalorrraqueano de pacientes com doença de Alzheimer e outras demências: resultados preliminares

RESUMO - A doença de Alzheimer (DA) se caracteriza pelo achado anátomo-patológico de acúmulo de placas senis e emaranhados neurofibrilares associados à proteína tau no tecido cerebral. A pesquisa por marcadores biológicos antemortem está focada nas concentrações das proteínas $\beta$-amilóide e tau no líquido cefalorraqueano (LCR) objetivando um diagnóstico mais precoce e acurado da doença. Os níveis de proteína tau hiperfosforilada no sítio 181 foram determinados no LCR de 34 pacientes com DA (19 com DA senil - DAS e oito com DA pré-senil -DAPS) e sete pacientes com outras demências (OD). Os níveis de fosfotau foram significativamente mais elevados em pacientes com DA quando comparados com OD (AUC 0,812), sem relação com gravidade da demência, idade de início, duração da doença e escores do MiniExame do Estado Mental. Não foram observadas diferenças entre os níveis de fosfotau em pacientes com DAS e DAPS. Estes achados corroboram os dados encontrados em estudos prévios e indicam que o nível de fosfotau no LCR dos pacientes pode colaborar na diferenciação da DA com outras demências.
\end{abstract}

PALAVRAS-CHAVE: doença de Alzheimer, diagnóstico diferencial, líquido cefalorraqueano, proteína tau.

Alzheimer's disease (AD) is the main cause of dementia in Western countries, being responsible for more than $50 \%$ of the cases ${ }^{1}$. The clinical diagnosis of $A D$ is characterized by an exclusionary process. The definite diagnosis is possible only on neuropathological examination, by the observation of the senile plaques and the neurofibrillary tangles
(NFTs) in the cerebral tissue ${ }^{2}$. The NFTs are intraneuronal cytoplasmatic structures composed by paired helical filaments (PHFs) of hyperphosphorylated form of the microtubule-associated protein tau. In AD, these NFTs are localized preferentially in pyramidal cells of the hippocampus and entorhinal cortex, in supragranular (II and III) and infragra-

\footnotetext{
${ }^{1}$ Postgraduate student, Department of Neurology, University of São Paulo School of Medicine, São Paulo SP, Brazil (FMUSP); ${ }^{2}$ Neurologist, Department of Clinics Discipline of Neurology, Federal University of Curitiba PR, Brazil (UFPR); ${ }^{3}$ Associated Professor, Department of Neurology, FMUSP; ${ }^{4}$ Graduate Student, Department of Neurology, FMUSP; ${ }^{5}$ Assistant Professor, Department of Neurology, FMUSP.
}

Received 24 November 2003, received in final form 8 May 2004. Accepted 7 June 2004.

Dra. Ana Paula B.J. Hartmann - Rua Francisco de Vitória 250/81 - 04116-180 São Paulo SP - Brasil. E-mail: aphartmann@uol.com.br 
nular ( $\mathrm{V}$ and $\mathrm{VI}$ ) layers of associative cortical areas. Subcortical areas are also affected, such as the nucleus basalis of Meynert, amygdala, locus ceruleus and dorsal raphe nuclei ${ }^{3}$.

The well established relationship between the density of NFTs and the severity of the dementia in $A D$ has lead to many studies about protein tau levels, one of the main components of NFTs, in cerebrospinal fluid (CSF) of AD patients ${ }^{4-6}$. Tau protein is a microtubule-associated protein (MAP) found basically in neurons and mainly localized in axons where it confers stability to microtubule components of the cytoskeleton. The protein is codified by a gene on chromosome 17 and mutations are associated to certain forms of frontotemporal dementia, especially frontotemporal dementia and parkinsonism related to chromosome $17^{7}$. Microtubule stability depends on phosphorylation of tau protein. In mature CNS low phosphorylated forms of tau protein predominate, maintaining adequate neuronal homeostasis. PHF-tau concentrations has been shown to be elevated in the cortex of AD patients while normal tau concentration is decreased ${ }^{8}$. Considering early and accurate diagnosis and differential diagnosis with other dementias that mimic AD symptoms, the development of a biological marker is of great value. A biological marker has a minimum of five functions: a) diagnostic confirmation; b) screening; c) predictive testing; $d$ ) monitoring disease progression and treatment; and e) analysis of the relation between brain-behavior ${ }^{9}$.

In this way, an ideal biomarker for AD should be: able to detect a characteristic pathological finding of $A D$; validated in $A D$ pathologically confirmed cases; precise (for differential diagnosis); trustable; not invasive; simple, reproductive; and not expensive.

Besides, it should have sensitivity and specificity above $80 \%$ and a positive predictive value above than $90 \%{ }^{9}$. The combination of biomarkers improves the diagnostic accuracy when compared to a single marker, thus increasing the sensitivity and specificity of the tests. Considering these factors, recent studies have been dedicated to investigate the abnormal proteins found in the CSF of $A D$ patients $4,10,11$. These studies have evaluated the levels of MAP-tau, primary component of the neurofibrillary tangles, and the $A \beta 42$ form of the $\beta$-amyloid protein, the main component of the senile plaques found in the cerebral parenchyma.

Many groups have shown an increase in tau levels $^{4,5,8,10,12,13}$ and a decrease in $A \beta 42$ levels ${ }^{13,14,15}$ in the CSF of AD patients when compared to non-de- mented elderly controls. The more recent longitudinal studies use the combination of high tau and low $A \beta 42$ to correlate their levels to the stage of the disease ${ }^{13,15}$. Since amyloid deposition is not exclusive of $A D$ brains, occurring in normal aging and also in other neurological diseases, additional investigation have shown a decrease in A $\beta$ CSF levels in other conditions such as Creutzfeldt-Jakob disease (CJD) ${ }^{16}$, some cases of frontotemporal dementia (FTD) and vascular dementia (VD) ${ }^{17}$.

In 1993, Vandermeeren et al. ${ }^{18}$ developed an immunoassay able to detect tau protein in CSF and subsequent studies concluded that its levels were significantly higher in AD patients when compared to other neurological diseases and normal controls even in the early stages of the disease $\mathrm{e}^{4,10}$. As tau protein is present in blood in a very low concentration, (under the detection limit of the immunoassay), the high levels in CSF do not reflect an alteration in blood brain barrier ${ }^{18}$. As elevated tau levels were also found in other neurological diseases, it was noticed that these immunoassays were measuring total tau, i.e., normal and abnormal tau protein. To solve this overlap, a group of investigators ${ }^{19}$ developed a method able to detect hyperphosphorylated tau (phosphotau) and obtained elevated levels when comparing $A D$ patients to controls. Other studies reproduced these results, suggesting that phosphotau is a more specific biomarker then total tau for $A D$ diagnosis ${ }^{20,21}$. The abnormal phosphorylation of tau protein is an early event in $A D$ pathophysiology and is restricted to cerebral regions affected by the disease. This hyperphosphorylation is the primary and the most critical event in PHFs and NFTs processing ${ }^{22}$. More than 21 sites of abnormal tau protein phosphorylation are known. As CSF tau concentrations are low, phosphotau is only identified by highly sensitive immunoassays using phospho-specific antibodies.

Several research groups standardized synthetic phosphopeptides in order to access the proline rich region of tau protein where the phosphosites are localized. Until now, different immunoassays were developed directed to different phosphosites as serine 199 , threonine 231 , serine $396 / 404$, threonine 231/serine 235 and threonine 18121,23. Vanmechelen et al. ${ }^{24}$ developed an ELISA assay specific for the phosphorylation site proline-directed to Thr 181. This site has been chosen because 1) it is a relatively isolated site in the proline rich region; 2 ) it is phosphorylated preferentially by kinases proline-directed; and 3) the synthetic peptide utilized for the standardization is small. The 
design of this peptide was based on detailed mapping of phosphotau and its antibodies, recognizing all tau isoforms. The objectives of the present study were to compare CSF phosphotau levels between senile (SAD) and presenile (PSAD) AD groups, between $A D$ patients and other dementias (OD), between $A D$ patients and controls from the literature $^{11}$, and, within the $A D$ group, to correlate phosphotau levels and severity of dementia, mini mental state examination (MMSE) scores and duration of the disease.

\section{METHOD}

A total number of 34 individuals were included in the study. Their main demographic and clinical characteristics are depicted in Table 1.

The subjects evaluated were consecutively selected from the population of patients followed at the Behavioral and Cognitive Neurology Unit of the Hospital das Clínicas from the University of São Paulo School of Medicine (HCFMUSP).

All patients were submitted to a diagnostic workup investigation, including clinical history, physical and neurological examination, appropriate blood tests (to exclude other causes of dementia), CT and/or brain MRI and other complementary exams if necessary.

In every case, the clinical diagnosis was made before CSF examination. No patient was on treatment with cholinesterase inhibitors or was participating in any protocol of new drugs before the lumbar puncture.

The diagnosis of probable AD was based on the NINCDS-ADRDA criteria ${ }^{25}$. For the AD group according to DSM-III-R criteria, the severity of dementia was classified as mild, moderate or severe. The diagnosis of frontotemporal dementia (FTD) was made according to the Lund/Manchester criteria ${ }^{26}$. Vascular dementia (VD) patients were selected according to probable VD criteria of NINDS-AIREN ${ }^{27}$ and dementia with Lewy bodies according to McKeith et al. criteria ${ }^{28}$. Criteria used to diagnosis of primary progressive aphasia (PPA) were those defined by Mesulam ${ }^{29}$.

Patients were divided in three groups: SAD (senile $A D$ ), PSAD (presenile $A D$ ) and OD (other dementias), with the latter including one patient with the diagnosis of
PPA, two cases of FTD, one with VD, one with corticobasal degeneration (CBD) and two with dementia with Lewy bodies (DLB).

CSF phosphotau analysis was performed using the kit INNOTEST ${ }^{\text {TM }}$ PHOSPHO-TAU (181P) (Innogenetics, Ghent, Belgium). The phosphotau levels from each of the patients' groups were compared to a subset of controls (composed of 32 individuals) extracted from a previously published study. ${ }^{11}$ These individuals were aged $63 \pm 9$ years and had no history, symptoms or signs of psychiatric or neurological disease, malignant or systemic disorders. The mean MMSE score in this group was $28.3 \pm 2.7$.

CSF analysis - All CSF samples were obtained by lumbar puncture. An approximate volume of $12 \mathrm{ml}$ was collected in polypropylene tubes and submitted to routine analysis (cytology, biochemistry and protein electrophoresis, as well as immunology for syphilis, cysticercosis and ADA measurement), always within a six-hour interval after the collection procedure. Samples with more than 500 erythrocytes $/ \mathrm{mm}^{3}$ were not included. After routine analysis and centrifugation of the material at $1500 \mathrm{rpm}$ for 10 minutes, the samples destined to phosphotau measurement were identified and stored at $-70^{\circ} \mathrm{C}$ freezer in the CSF laboratory.

An enzymatic immunoassay in solid phase for the quantitative determination of phosphotau in human CSF standardized in the kit INNOTESTTM PHOSPHO-TAU ${ }_{(181 \mathrm{P})}$ (Innogenetics, Ghent, Belgium) was the method used for this evaluation.

The study was approved by the Ethics Committee of the HCFMUSP and all participants signed a written informed consent.

Statistical analysis - The comparison between phosphotau levels in AD groups and controls from literature was made by the Student's $t$ test. The comparison between $A D$ and $O D$ groups was made by the MannWhitney test. In the AD group, the correlation between phosphotau levels and severity of dementia, MMSE scores and duration of the disease was made by the Spearman's rank correlation test.

\section{RESULTS}

Due to difficulties in obtaining CSF samples from normal controls, we have been unable to

Table 1. Main demographic and clinical characteristics of the patients.

\begin{tabular}{lcccccc}
\hline Diagnosis & $\mathrm{N}$ & $\begin{array}{c}\text { Gender } \\
(\mathrm{M}: \mathrm{F})\end{array}$ & $\begin{array}{c}\text { Age (years) } \\
\text { mean }\end{array}$ & $\begin{array}{c}\text { Schooling } \\
\text { (years)mean }\end{array}$ & $\begin{array}{c}\text { Duration disease } \\
\text { (years) mean }\end{array}$ & $\begin{array}{c}\text { MMSE } \\
\text { scores mean }\end{array}$ \\
\hline S AD & 19 & $08: 11$ & 75.5 & 5.7 & 5.0 & 16.5 \\
PS AD & 08 & $1: 7$ & 62.5 & 7.5 & 4.0 & 16.5 \\
OD & 07 & $6: 1$ & 67 & 8.9 & 2.1 & 12.5 \\
\hline
\end{tabular}

N, number of patients; M, male; F, female; MMSE, Mini-Mental status examination; S AD, senile Alzheimer's disease; PS AD, presenile Alzheimer's disease; OD, other dementias. 
Table 2. Mean ( \pm SD) levels of phosphotau.

\begin{tabular}{cc}
\hline \multicolumn{2}{c}{ Levels of CSF phosphotau $(\mathrm{pg} / \mathrm{ml})$} \\
\hline & Mean $( \pm \mathrm{SD})$ \\
S AD & $49.78( \pm 36.09)$ \\
PS AD & $44.06( \pm 33.29)$ \\
OD & $15.01( \pm 27.05)$ \\
\hline
\end{tabular}

S AD, senile Alzheimer's disease; PS AD, presenile Alzheimer's disease; OD, other dementias.

establish sensitivity and specificity of the method as we could not define cut-off values for the analysis of the results obtained in this study. We tried to overcome this limitation by comparing our results of phosphotau levels with controls described in the literature ${ }^{11}$.

The statistical analysis showed no significant difference between SAD, PSAD and OD groups according to duration of the disease $(p=0.644)$, education $(p=0.830)$, severity of dementia $(p=0.481)$ and MMSE scores $(p=0.651)$. As expected, there was a significant age difference between SAD and PSAD groups $(p=0.000)$. Significant differences were also observed between the AD and OD groups for age $(p=0.013)$, which was lower in the latter, and gender $(p=0.035)$ with women predominating in the $A D$ group and men in OD.

Using the mean of phosphotau levels of control individuals obtained from a previous study $(32.8 \mathrm{pg} / \mathrm{ml})^{11}$, we obtained a significant difference $(p=0.013)$ between AD patients and controls. The mean phosphotau concentration in the $A D$ group was $50.4 \mathrm{pg} / \mathrm{ml}$. No differences were observed between phosphotau levels of SAD and PSAD groups $(p=0.549)$ as it is depicted in Table 2.

There was no significant correlation, in the AD group, between levels of phosphotau and severity of dementia $(r=-0.082)$, duration of disease $(r=0.015)$ and MMSE scores $(r=-0.020)$.

A significant difference was found between phosphotau levels of AD and OD groups $(p=0.023)$. Plotting the values of phosphotau levels from the $A D$ and $O D$ groups in a Receiving Operator Characteristics (ROC) curve we found that phosphotau levels differentiated AD from OD patients, what was confirmed with an area under the curve (AUC) of 0.812 (Fig 1).

\section{DISCUSSION}

In the present study CSF levels of phosphotau were increased in $A D$ patients when compared to

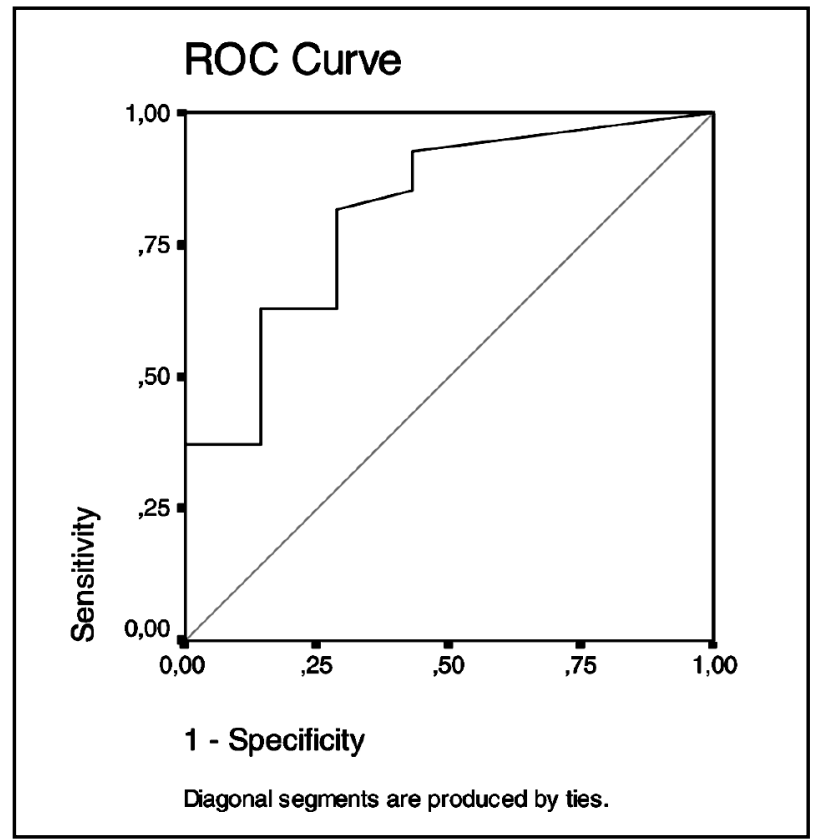

Fig 1. Values of phosphotau levels from $A D$ and $O D$ groups.

normal controls from the literature and to patients with OD, a finding that is similar to previous reports $11,20,21,23,24$. However, It is important to reinforce that phosphotau levels in a normal range do not exclude AD. The absence of a correlation between phosphotau levels and severity of dementia suggests that this elevation is an early event in AD pathogenesis. Indeed, some studies demonstrated the clinical value of this biomarker in the early stages of $A D^{11,30}$.

Two patients with other dementias in the present study presented high levels of phosphotau (one case with FTD and one case with DLB). Although it is not possible to exclude the hypothesis of diagnostic errors, the long follow-up of all these patients, before and after the CSF analysis, is a feature that certainly increases the diagnostic confidence within this sample.

The utilization of additional biomarkers, such as the combination $A \beta_{1-42}$ protein with phosphotau, and its correlation with the clinical presentation, certainly would have given a higher diagnostic sensitivity and specificity. This fact was recently confirmed in a meta-analysis that included all the studies that evaluated the combination of biomarkers in an expressive number of patients and using an adequate diagnostic method of the cause of dementia ${ }^{14}$. Unfortunately, it has not been possible to verify the diagnostic values of this combination in the present study. 
Additional studies are necessary to establish a methodological standardization of CSF immunoassays between the research centers and to observe if they represent a very high specificity for AD diagnosis, mainly in relation to forms of dementia that present an important overlap with $A D$ either on clinical and on pathological examination (such as DLB and VD). Moreover, the conflicting findings from the literature, correlating CSF biomarkers with clinical severity measures of dementia, suggest the need of larger samples to establish a confident statistical significance. The reason for this variability is probably due to the fact that a single marker is not able to reflect precisely the central pathological process of each stage of the disease.

Maybe a potential utility of such biomarkers is in the follow-up of individuals at risk of developing $A D$ in prospective studies. However, much work is still necessary to standardize assay methods before the determination of the prognostic value attributable to these biomarkers. With the definition of well standardized values, in large populations, it is possible that gradual alterations in these levels can be interpreted as suggestive evidences of incipient AD. To test this hypothesis, longitudinal studies including large samples of elderly individuals are necessary.

In conclusion, the present study found that CSF levels of phosphotau analysis is a good biomarker for $A D$ and is able to help in differentiating $A D$ from other dementias, independently of the age of onset, severity of dementia or MMSE scores.

\section{REFERENCES}

1. Herrera E Jr, Caramelli P, Silveira AS, Nitrini R. Epidemiologic survey of dementia in a community-dwelling Brazilian population. Alzheimer Dis Assoc Disord 2002;16:103-108.

2. Mirra SS, Heyman A, McKeel D et al. The Consortium to Establish a Registry for Alzheimer's Disease (CERAD): part II. Standardization of the neuropathologic assessment of Alzheimer's disease. Neurology 1991;41:479-486.

3. Wisniewski HM, Robe A, Zigman W, Silverman W. Neuropathological diagnosis of Alzheimer disease. J Neuropathol Exp Neurol 1989;48:606-609.

4. Arai H, Clark CM, Ewbank DC, et al. Cerebrospinal fluid tau protein as a potential diagnostic marker in Alzheimer's disease. Neurobiol Aging 1998;19:125-126.

5. Blennow K, Wallin A, Agren H, Spenger C, Siegfried J, Vanmechelen E. Tau protein in cerebrospinal fluid: a biochemical marker for axonal degeneration in Alzheimer disease? Mol Chem Neuropathol 1995;26:231-245.

6. Galasko D, Hansen L Vigo-Pelfrey C, et al. Antemortem CSF tau is related to neuronal pathology at autopsy in Alzheimer's disease. Soc Neurosci Abstr 1995;581.

7. Bramblett GT, Goedert M, Jakes R, Merrick SE, Trojanowski JQ, Lee VM. Abnormal tau phosphorylation at Ser396 in Alzheimer's disease recapitulates development and contributes to reduced microtubule binding. Neuron 1993;10:1089-1099.

8. Vigo-Pelfrey C, Seubert P, Barbour R, et al. Elevation of microtubuleassociated protein tau in the cerebrospinal fluid of patients with Alzheimer's disease. Neurology 1995;45:788-793.
9. Consensus report of the Working Group on: "Molecular and Biochemical Markers of Alzheimer's Disease". The Ronald and Nancy Reagan Research Institute of the Alzheimer's Association and the National Institute on Aging Working Group. Neurobiol Aging 1998;19:109-116.

10. Andreasen N, Minthon L, Vanmechelen E, et al. Cerebrospinal fluid tau and Abeta42 as predictors of development of Alzheimer's disease in patients with mild cognitive impairment. Neurosci Lett 1999;273:5-8.

11. Andreasen N, Vanmechelen E, Vanderstichele H, et al. Cerebrospinal fluid levels of total-tau, phospho-tau and AB42 predicts development of Alzheimer's disease in patients with mild cognitive impairment. Acta Neurol Scand. 2003;179:(Suppl)47-51.

12. Hu YY, He SS, Wang XC, et al. Elevated levels of phosphorylated neurofilament proteins in cerebrospinal fluid of Alzheimer disease patients. Neurosci Lett 2002;320:156-160.

13. Shoji M, Matsubara E, Kanai M, et al. Combination assay of CSF tau, A beta 1-40 and A beta 1-42(43) as a biochemical marker of Alzheimer's disease. J Neurol Sci 1998;158:134-140.

14. Sunderland T, Linker G, Mirza N, et al. Decreased B-amyloid and increased tau levels in cerebrospinal fluid of patients with Alzheimer's disease. JAMA 2003;289:2094-2103.

15. Kanai M, Matsubara $E$, Isoe $K$, et al. Longitudinal study of cerebrospinal fluid levels of tau, A beta1-40, and A beta1-42(43) in Alzheimer's disease: a study in Japan. Ann Neurol 1998;44:17-26.

16. Kapaki E, Kilidireas K, Paraskevas GP, Michalopoulou M, Patsouris E. Highly increased CSF tau protein and decreased beta-amyloid (1-42) in sporadic CJD: a discrimination from Alzheimer's disease? J Neurol Neurosurg Psychiatry 2001;71:401-403.

17. Riemenschneider M, Wagenpfeil S, Diehl J, et al. Tau and Abeta42 protein in CSF of patients with frontotemporal degeneration. Neurology 2002;58:1622-1628.

18. Vandermeeren M, Mercken M, Vanmechelen E, et al. Detection of tau proteins in normal and Alzheimer's disease cerebrospinal fluid with a sensitive sandwich enzyme-linked immunosorbent assay. J Neurochem 1993;61:1828-1834.

19. Ishiguro $\mathrm{K}$, Ohno H Arai $\mathrm{H}$, et al. Phosphorylated tau in human cerebrospinal fluid is a diagnostic marker for Alzheimer's disease. Neurosci Lett 1999;270:91-94.

20. Vanmechelen E, Van Kerschaver E, Blennow K, et al. CSF-phosphotau (181P) as a promising marker for discriminating Alzheimer's disease from dementia with Lewy bodies. In Iqbal K, Sisodia SS, Winblad B (eds). Alzheimer's disease: advances in ethiology, pathogenesis and therapeutics. Chichester: John Willey Sons; 2001:285-291.

21. Parnetti L, Lanari A, Amici S, Gallai V, Vanmechelen E, Hulstaert F. CSF phosphorylated tau is a possible marker for discriminating Alzheimer's disease from dementia with Lewy bodies. Phospho-Tau International Study Group. Neurol Sci2001;22:77-78.

22. Kopke E, Tung YC, Shaikh S, Alonso AC, Iqbal K, Grundke-Iqbal I. Microtubule-associated protein tau: abnormal phosphorylation of a non- paired helical filament pool in Alzheimer disease. J Biol Chem 1993;268:24374-24384.

23. Sjogren M, Davidsson P, Tullberg M, et al. Both total and phosphorylated tau are increased in Alzheimer's disease. J Neurol Neurosurg Psychiatry 2001;70:624-360.

24. Vanmechelen E, Vanderstichele H, Davidsson P, et al. Quantification of tau phosphorylated at threonine 181 in human cerebrospinal fluid: a sandwich ELISA with a synthetic phosphopeptide for standardization. Neurosci Lett 2000;285:49-52.

25. McKhann G, Drachman D, Folstein M, Katzman R, Price D, Stadlan EM. Clinical diagnosis of Alzheimer's disease: report of the NINCDS-ADRDA Work Group under the auspices of Department of Health and Human Services Task Force on Alzheimer's Disease. Neurology 1984;34:939-944.

26. Clinical and neuropathological criteria for frontotemporal dementia The Lund and Manchester Groups. J Neurol Neurosurg Psychiatry 1994;57:416-418.

27. Erkinjuntti T. Clinical criteria for vascular dementia: the NINDS-AIREN criteria. Dementia 1994;5:189-192.

28. McKeith IG, Galasko D, Kosaka K, et al. Consensus guidelines for the clinical and pathologic diagnosis of dementia with Lewy bodies (DLB): report of the consortium on DLB international workshop. Neurology 1996;47:1113-1124.

29. Mesulam M, Mesulam M. Clinical Neurology. International practice and research: unusual dementias. Guest Edition. MN Rossor, 1992.

30. Buerger K, Teipel SJ, Zinkowski R, et al. CSF tau protein phosphorylated at threonine 231 correlates with cognitive decline in MCI subjects. Neurology 2002;59:627-629. 